\title{
Timber Thinning and Prescribed Burning as Methods to Increase Herbage on Grazed and Protected Longleaf Pine Ranges
}

\author{
GALE L. WOLTERS
}

\begin{abstract}
Selective commercial timber thinning and prescribed burning are effective tools in maintaining a productive forage resource on stocked range of longleaf pine (Pinus palustris). Productive mixtures of herbaceous species can be sustained through periodic timber thinning to maintain 12 to $20 \mathrm{~m}^{2} / \mathrm{ha}$ of longleaf pine basal area and rotational winter burning, at 3-year intervals. Two to three years of heavy use can be expected after patch cutting if the area of patch cuts constitute a minor percentage of the total grazed range unit. Heavy use may convert patch cuts predominantly to carpetgrass and forested range to a mixture of forbs.
\end{abstract}

Pine plantations throughout the South can be managed for concurrent production of wood fiber and forage (Pearson et al. 1971, Grelen and Enghardt 1973, and Hart et al. 1970). With proper management, continuous grazing by cattle is not detrimental to establishing and growing artificially regenerated pine plantations (Pearson et al. 1971), nor is forage production seriously diminished by pine canopies until plantations approach 10 years of age (Wolters 1973).

Many longleaf pine (Pinus palustris) plantations are rapidly approaching or have already attained commercial timber size and could be thinned to generate immediate cash income. Observations and available literature suggest that selective tree removal or patch cutting within a plantation drastically alters forage production and livest ock utilization patterns; thus, the current study was started to determine what effects the rate of tree removal had on concurrent forage production, its botanical composition, and utilization by cattle when the range was burned by controlled backfire every third year. Findings will facilitate development of guidelines to integ rate management of timber and forage on longleaf pine ranges.

\section{Study Area}

The study was conducted on the Longleaf Tract, Palustris Experimental Forest, in central Louisiana. The 5.18-ha study area was approximately centered in a stand of longleaf pine planted on $1.83-\mathrm{m}$ by $1.83-\mathrm{m}$ spacings during February 1952. In 1969, prior to any timber cutting, the plantation was stocked with an average of 1, 194 longleaf pine trees per ha, with a standard error of the mean of 57.3 based on a sample of $24,0.04$-ha plots. The herbaceous understory consisted principally of pinehill bluestem (Andropogon scoparius var. divergens) and slender bluestem $A$. tener), but other bluestems and several species of panicums (Panicum spp.) and paspalums (Paspalum spp.) were also common. The study area was located in a 182.1-ha range unit moderately grazed by cattle yearlong, since prior to reforestation. One half of the study area, 2.59-ha, was fenced in 1960 and protected from grazing.

The author was formerly principal range scientist, Southern Forcst Expcriment Station, Forest Service, U.S. Department of Agriculture, Alexandria, La., and is now with Forest Environment Research Staff, Forest Service, U.S. Department of Agriculture, Washington, D.C.

Manuscript received March 25, 1980

\section{Experimental Procedure}

Both the grazed and protected study units were divided equally into four blocks, each block subdivided into four 0.16-ha plots. Four hasal area treatments $\left(0,12.63,16.07\right.$, and $19.51 \mathrm{~m}^{2}$ of pine basal area/ha, referred to as patch cut, low, moderate, and high basal area treatments, respectively) were randomly assigned to the four plots in each block, comprising a complete randomized block design. All pines were removed from the protected patch cuts during winter 1959-1960. Pines were cleared from grazed patch cuts during the 1969 growing season. Forested treatments were thinned initially during the 1969 growing season and again during the 1973 growing season. Pine regeneration did not occur on any treatments during the study.

All vegetation measurements were collected within a 0.04-ha sampling area centered in each 0.16 -ha plot. Thus, each sampling area was surrounded by a $10.06-\mathrm{m}$ wide isolation strip. Beginning in 1969, all trees with $2.54-\mathrm{cm}$ diameters (dbh) or greater on the 0.04-ha plots were measured annually during the dormant season. Basal area in $\mathrm{m}^{2}$ / ha was calculated from diameter measurements. Herbage standing crop was measured annually from 1969 through 1975 on protected units and from 1970 through 1975 on grazed units. Botanical composition of herbage was determined in 1969 on protected units and in 1972 and 1975 on both grazed and protected units. Herbage standing crop and botanical composition were determined in November of each year from a pooled estimate of eight systematically located $0.472-$ by $0.472-\mathrm{m}\left(.223-\mathrm{m}^{2}\right)$ clipping quadrats on each 0.04-ha sampling area. Herbage was clipped, separated by species or species group, bagged, oven-dried, weighed, and converted to $\mathrm{kg} / \mathrm{ha}$. On areas grazed by cattle, herbage standing crop and botanical composition was estimated through the use of caged quadrats moved annually similar to the stationary-cage procedure described by Grelen (1967). Cages were constructed of 12-gage woven wire; were approximately $75 \mathrm{~cm}$ tall and $120 \mathrm{~cm}^{2}$ at the base. Herbage utilization was calculated as the percentage of herbage disappearance determined by the difference in residual herbage remaining on grazed $0.223-\mathrm{m}^{2}$ quadrats compared to standing crop on adjacent caged quadrats.

The plantation was burned by head fire in January 1955 to control brown spot needle blight, and controlled backfires were applied to the plantation every third year, in March, from 1960 through 1975. In addition, the area was prescribed burned by controlled backfire in March 1975 to reduce thinning slash remaining after the 1973 commercial timber harvest.

The experimental area consisted of two completely independent units-one grazed, one protected from grazing. Since only one herd of cattle was involved, vegetation responses to grazing or protection from grazing could not be statistically analyzed, although treatment means are presented. All data were tested by Tukey's $w$-proced ure; herbage standing crop association with pine basal area, the independent variable, was tested by regression analysis (Steel and Torrie 1960). Differences were tésted for significance at the $5 \%$ probability level. 


\section{Results and Discussion}

\section{Herbage Utilization}

In the first two complete growing seasons after removal of pines (1970 and 1971), cattle grazed patch cuts located throughout forested longleaf pine stands more intensively than adjacent forested range (Table 1). From 1970 through 1972, the rate of herbage utilization on forested ranges tended to increase annually, whereas, the rate decreased on patch cuts until 1972, when utilization was similar on patch cut and forested treatments. Following additional tree removal from forested treatments in 1973, a distinct high rate of use, characterized by very short grass stubble, was observed around every freshly cut longleaf pine stump. Observations indicated that cattle also intensively utilized herbage around the base of standing dead trees the first 2 or 3 years after a tree died. Apparently, when a longleaf pine dies, whether due to natural mortality or a severed bole, some chemical change occurs in adjacent herbaceous plants which cattle seek.

Table 1. Herbage utilization $(\%)$ by residual longleaf pine basal area treatment and year.

\begin{tabular}{lcccc}
\hline \hline & \multicolumn{4}{c}{ Residual pine basal area treatment' } \\
\cline { 2 - 5 } Year & High & Moderate & Low & Patch cut \\
\hline 1970 & $37.8 \mathrm{~b}$ & $8.3 \mathrm{~b}$ & $24.3 \mathrm{~b}$ & $94.3 \mathrm{a}$ \\
1971 & $35.5 \mathrm{~b}$ & $28.5 \mathrm{~b}$ & $29.8 \mathrm{~b}$ & $79.0 \mathrm{a}$ \\
1972 & $54.0 \mathrm{a}$ & $65.8 \mathrm{a}$ & $59.5 \mathrm{a}$ & $64.8 \mathrm{a}$ \\
1973 & $52.0 \mathrm{a}$ & $51.8 \mathrm{a}$ & $35.8 \mathrm{ab}$ & $16.8 \mathrm{~b}$ \\
1974 & $67.3 \mathrm{a}$ & $60.8 \mathrm{a}$ & $51.5 \mathrm{a}$ & $70.0 \mathrm{a}$ \\
1975 & $52.5 \mathrm{a}$ & $37.0 \mathrm{a}$ & $41.8 \mathrm{a}$ & $12.5 \mathrm{~b}$ \\
\hline
\end{tabular}

I Within-row values followed by similar subscripts indicate no significant difference at the $5 \%$ level of probability.

The utilization rate on the patch cuts in 1973-four growing seasons after the trees were harvested -indicates that cattle generally selected herbage other than that on old patch cuts. In 1974, after the slash reduction burn, utilization on the patch cuts was similar to that on forested sites, as in 1972, the first year after a burn. Patch cut herbage was not utilized again in 1975; however, 1975 was also a first-year burn, but utilization rates were dissimilar on patch cuts and forested range. Apparently, complex time interactions exist between tree mortality and burning that influence herbage preference, but corroborative documentation is lacking.

Herbage utilization rates on patch cuts were greater than reported for cutover range by Duvall and Whitaker (1964). Several factors may have contributed to these unusually high utilization rates: patch cuts were freshly cut and cattle apparently prefer these areas to old cutover range; also, the patch cut areas amounted to only about $2 \%$ of the entire grazing unit and even a slight preference for forage on patch cuts would concentrate use on preferred areas.

Evidently herbage utilization patterns can be modified by longleaf pine tree removal; however, additional study is needed to fully quantify these effects. A cut-burn-graze process immediately preceding pine regeneration may prove beneficial by reducing competition from herbaceous vegetation.

\section{Botanical Composition}

Pinehill bluestem was the principal herbaceous species on protected range regardless of residual longleaf pine basal area (Table 2). Pinehill bluestem and slender bluestem combined produced about 50 to $60 \%$ of the herbage on protected range in 1969 and 1972, but both species tended to diminish in importance in 1975. Residual basal area treatments influenced the proportion of bluestems only in 1975 when slender bluestem occurred in greater proportions on patch cuts than on high or moderate basal area treatments. Other bluestems, consisting of a nearly equal mixture of broomsedge ( $A$. virginicus), Elliott ( $A$. elliottii), fineleaf ( $A$. subtenuis), and paintbrush (A. ternarius), varied considerably within and between treatments and years but generally was not a
Table 2. Percent botanical composition of herbaceous vegetation on protected range by residual longleaf pine basal area treatment and year.

\begin{tabular}{|c|c|c|c|c|}
\hline \multirow[b]{2}{*}{ Year/herbage component } & \multicolumn{4}{|c|}{ Residual pine basal area treatment ${ }^{1}$} \\
\hline & High & Mod & Low & Patch cut \\
\hline \multicolumn{5}{|l|}{ 1969: } \\
\hline Carpetgrass & 0 & 0 & 0 & \\
\hline Pinehill bluestem & 52 & 39 & 58 & 43 \\
\hline Slender bluestem & 10 & 6 & 9 & 18 \\
\hline Other bluestems & 7 & 24 & 4 & 8 \\
\hline Panicums & 10 & 18 & 10 & 9 \\
\hline Other grasses and grasslikes & 14 & 6 & 12 & 14 \\
\hline Forbs & 7 & 7 & 7 & 8 \\
\hline Total & 100 & 100 & 100 & 100 \\
\hline
\end{tabular}

1972:

\begin{tabular}{|c|c|c|c|c|}
\hline Carpetgrass & 0 & 0 & 0 & 0 \\
\hline Pinehill bluestem & 26 & 56 & 45 & 33 \\
\hline Slender bluestem & 21 & 4 & 7 & 21 \\
\hline Other bluestem & $\mathrm{T}^{2}$ & 4 & 1 & 6 \\
\hline Panicums & 21 & 12 & 17 & 7 \\
\hline Other grasses and grasslikes & 20 & 12 & 13 & 26 \\
\hline Forbs & 12 & 12 & 17 & 7 \\
\hline Total & 100 & 100 & 100 & 100 \\
\hline
\end{tabular}

1975:

\begin{tabular}{|c|c|c|c|c|}
\hline Carpetgrass & 0 & 0 & 0 & 0 \\
\hline Pinehill bluestem & 23 & 32 & 35 & 37 \\
\hline Slender bluestem & $5 b$ & $7 b$ & $9 a b$ & $22 \mathrm{a}$ \\
\hline Other bluestems & 10 & 14 & 9 & 2 \\
\hline Panicums & 22 & 15 & 9 & 4 \\
\hline Other grasses and grasslikes & 14 & 13 & 4 & 30 \\
\hline Forbs & $26 a$ & $19 \mathrm{ab}$ & $34 a$ & $5 b$ \\
\hline Total & 100 & 100 & 100 & 100 \\
\hline
\end{tabular}

I Within-row values followed by dissimilar subscripts indicate significant difference at the $5 \%$ level.

${ }^{2} \mathrm{~T}$ equals less than $1 \%$.

major component of total herbage production.

Switchgrass ( $P$. virgatum) and several species of low panicums were the principal components of the panicums groups. Panicums generally produced in excess of $10 \%$ of the herbage on patch cuts, although treatment differences were nonsignificant. The proportion of herbage produced by the other grass and grasslike groupsincluding cutover muhly (Muhlenbergia expansa), arrowfeather threeawn (Aristida purpurascens), green silkyscale (Anthaenantia villosa), paspalums (Paspalum spp.), and species of the sedge (Cyperaceae) and rush families (Juncaceae) - was highly variable on forest treatments but tended to increase in importance with time on patch cuts. In fact, the proportion of other grasses and grasslikes on patch cuts increased from about $15 \%$ in 1969 to nearly $30 \%$ in 1975 principally due to the increase in cutover muhly. The proportion of other grasses and grasslikes was, however, similar under all protected treatment.

Forbs, of which the most common were grassleaf goldaster (Heterotheca graminifolia), swamp flower (Helianthus angustifolius), poor-joe (Diodia teres), southern bracken (Pteridium aquilinum var. pseudocaudatum), and a mixture of legumes, produced less than $10 \%$ of the herbage in 1969. The proportion of forbs increased with time on forested range but remained fairly stable on patch cuts. In 1975, forbs were generally more abundant on forested range than on patch cuts.

Botanical composition differed substantially due to the presence of carpetgrass on grazed range and its essential absence on protected range (Table 3 ). On grazed range, the proportion of carpetgrass was greater on patch cuts than forested treatments; however, the proportion of carpetgrass was probably influenced only indirectly by residual basal area treatment. Patch cuts probably were converted to carpetgrass primarily due to the high degree of herbage utilization. Earlier studies (Wahlenberg et al. 1939, Duvall and Linnartz 1967, and Wolters 1972) reported that heavy use 
Table 3. Percent botanical composition of herbaceous vegetation on grazed range by residual longleaf pine basal area treatment and year.

\begin{tabular}{|c|c|c|c|c|}
\hline \multirow[b]{2}{*}{ Year/herbage component } & \multicolumn{4}{|c|}{ Residual pine basal area treatment ${ }^{1}$} \\
\hline & High & Moderate & Low & Patch cut \\
\hline \multicolumn{5}{|l|}{ 1972: } \\
\hline Carpetgrass & $1 b$ & $3 b$ & $4 b$ & $24 \mathrm{a}$ \\
\hline Pinehill bluestem & 24 & 19 & 16 & 8 \\
\hline Slender bluestem & 6 & 5 & 5 & 9 \\
\hline Other bluestems & 3 & 3 & 11 & 3 \\
\hline Panicums & 26 & 33 & 18 & 35 \\
\hline Other grasses and grasslikes & 13 & 22 & 27 & 8 \\
\hline Forbs & 27 & 15 & 19 & 13 \\
\hline Total & 100 & 100 & 100 & 100 \\
\hline \multicolumn{5}{|l|}{ 1975: } \\
\hline Carpetgrass & $5 b$ & $4 b$ & $3 \mathrm{~b}$ & $50 \mathrm{a}$ \\
\hline Pinehill bluestem & 3 & 5 & 8 & 4 \\
\hline Slender bluestem & 9 & 4 & 14 & 7 \\
\hline Other bluestems & 1 & 2 & 1 & 9 \\
\hline Panicums & 15 & 22 & 14 & 10 \\
\hline Other grasses and grasslikes & 21 & 20 & 16 & 14 \\
\hline Forbs & $46 \mathrm{a}$ & $43 a$ & $44 a$ & $6 \mathrm{~b}$ \\
\hline Total & 100 & 100 & 100 & 100 \\
\hline
\end{tabular}

Within-row values followed by dissimilar subscripts indicate significant difference at the $5 \%$ level.

encourages the spread of carpetgrass, but proportionately rapidly diminishes with light or no use.

The proportions of pinehill bluestem, slender bluestem, and other bluestems were generally not influenced by silvicultural treatment. Although, these grasses generally produced a smaller proportion of the total herbage on grazed range than on protected range. Differences were not apparent in proportion of panicums and other grasses and grasslikes due to a residual basal area treatment on grazed range, although in 1972 a weedy species, pimple panicum ( $P$. brachyanthum), accounted for a large proportion of the panicum group on grazed range.

The proportion of forbs tended to increase with time on grazed range just as they did under protection. Also, in 1975 forbs were more common on forest range than on patch cuts. Poor-joe and white cupatorium (Eupatorium album) were the principal forbs under all basal area treatments; however, southern bracken was a common component on forested treatments but rarely existed on patch cuts. Poor-joe, white eupatorium, and southern bracken all appeared to be associated with site disturbance following timber thinning. Differences in herbage botanical composition between forested and patch cut range were discounted as causative factors influencing utilization. Findings suggest that pine overstory and

Table 4. Herbage production $(\mathrm{kg} / \mathrm{ha})$ by residual longleaf pine basal area treatment and year on grazed and protected range.

\begin{tabular}{lrrrr}
\hline & \multicolumn{4}{c}{ Residual pine basal area treatment ${ }^{1}$} \\
\cline { 3 - 5 } Year & High & \multicolumn{4}{c}{ Moderate } & Low & Patch cut \\
\hline \multicolumn{5}{c}{ Protected } \\
1969 & 791 & 1206 & 1403 & 2973 \\
1970 & 498 & 555 & 1329 & 3353 \\
1971 & 240 & 447 & 615 & 2715 \\
1972 & 193 & 262 & 619 & 2304 \\
1973 & 352 & 418 & 832 & 3450 \\
1974 & 688 & 1003 & 1363 & 3478 \\
1975 & 1049 & 1445 & 1660 & 3853 \\
& & & & \\
1970 & 440 & 720 & 801 & 2431 \\
1971 & 389 & 723 & 804 & 2756 \\
1972 & 233 & 546 & 760 & 2012 \\
1973 & 683 & 913 & 1342 & 3067 \\
1974 & 804 & 1139 & 1445 & 3310 \\
1975 & 913 & 1092 & 1819 & 2476 \\
\hline
\end{tabular}

rate of utilization influenced botanical composition rather than influencing the utilization rate.

\section{Herbage Standing Crop}

Annual standing crop on protected patch cuts averaged 3,161 $\mathrm{kg} /$ ha from 1969 through 1975 (Table 4). Standing crop on grazed patch cuts, determined by the cage technique, averaged $2,675 \mathrm{~kg}$ annually from 1970 through 1975 . Grelen (1967) reported that the stationary-cage technique overestimated herbage yield on grazed southern pine-bluestem range. If the technique does in fact overestimate yield the real differences in annual stand crop between protected and grazed patch cuts would be greater than indicated by the present data. True differences in standing crop on protected and grazed patch cuts was apparently due to either botanical composition, plant vigor, or a combination of both factors.

Forested range treatments produced less herbage than patch cuts. Under trees the standing crop diminished as competition with pines increased if level of residual basal area is used as a relative index to competition.

The association of annual herbage standing crop with residual pine basal a rea was tested by regression analysis, with all years pooled. The linear regressions explained 78 and $86 \%$ of the variation in standing crop in $\mathrm{kg} /$ ha on grazed $(\mathrm{G})$ and protected $(\mathrm{P})$ range, respectively (Fig. 1). Level of the two regressions were different and indicate that patch cut treatments protected from grazing were more productive than grazed patch cuts. The differences in stand crop were probably due to differences in botanical composition and plant vigor. Both composition and vigor could have been influenced by repeated defoliation and time since patch cut establishment. Protected patch cuts were established in 1960, thus herbs had 9 years to respond to the absence of pine trees before the study was initiated, whereas, grazed patch cuts were not established until 1969 and the full production potential of herbs may not have been attained throughout the duration of the study.

\section{Conclusions}

In the first two growing seasons after a patch cut and burn, herbage utilization by cattle averaged 94 and $79 \%$, respectively. Grazing preference shown by cattle for herbage from patch cuts diminished within 3 years after clearing. Herbage utilization rates

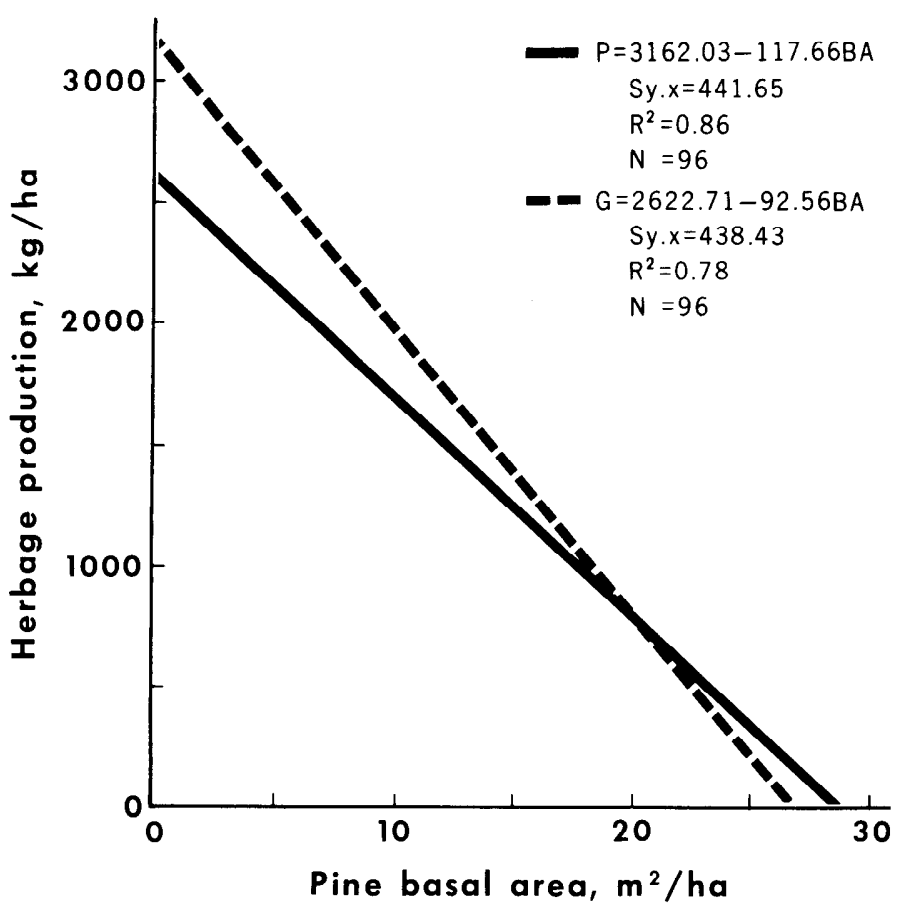

Fig. 1. Herbage production-pine basal area relationships on protected $(P)$ and grazed $(G)$ longleaf pine range. 
suggested that cattle reject herbage from old patch cuts range when herbage is available immediately adjacent to freshly cut pine stumps.

The amount of trees harvested and the duration lapsed since harvest appeared to be the principal factors influencing herbage utilization. These factors also contributed indirectly to modifying herbage botanical composition.

Pinehill bluestem was the principal forage species on protected range. Botanical composition was modified by grazing on both patch cut and forested range. Excessive use by cattle converted the principally bluestem range to forbs under a longleaf pine canopy and to carpetgrass on patch cuts. Within 3 and 6 years after the patch cut, carpetgrass produced 24 and $50 \%$ of the total herbage, respectively, on grazed range. Weed forbs and grasses increased in proportion to total herbage on forested ranges.

Though apparent differences in herbage production existed on grazed and protected ranges, herbage standing crop declined with increased increments of longleaf pine competition under both conditions. Differences in standing crop on grazed and protected range were probably due to differences in botanical composition and plant vigor. Longleaf pine plantations with 12 to $20 \mathrm{~m}^{2}$ of residual basal area produced approximately 800 to $1,650 \mathrm{~kg} / \mathrm{ha}$ of herbage annually.

\section{Literature Cited}

Duvall, V.L., and L.B. Whitaker. 1964. Rotation burning: A forage management system for longleaf pine-bluestem ranges. J. Range Manage. 17:322-326.

Duvall, V.L., and N.E. Linnartz. 1967. Influences of grazing and fire on vegetation and soil of longleaf pine-bluestem range. J. Range Manage. 20:241-247.

Grelen, Harold E. 1967. Comparison of cage methods for determining utilization on pine-bluestem range. J. Range Manage. 20:124-126.

Grelen, Harold E., and Hans G. Enghardt. 1973. Burning and thinning maintain forage in a longleaf pine plantation. J. Forest 71:419-420.

Hart, R.H., R.H. Huges, C.E. Lewis, and W.G. Monson. 1970. Effects of nitrogen and shading on yield and quality of grasses grown under young slash pine. Agron. J. 62:285-287.

Pearson, H.A., L.B. Whitaker, and V.L. Duvall. 1971. Slash pine regeneration under regulated grazing. J. Forest. 69:744-746.

Steel, R.G.D., and J.H. Torrie. 1960. Principles and Procedures of Statistics. McGraw-Hill Book Co., Inc. New York. 481 p.

Wahlenberg, W.G., S.W. Greene, and H.R. Reed. 1939. Effects of fire and cattle grazing on longleaf pine lands as studied at McNeill, Mississippi. U.S. Dep. Agr. Tech. Bull. 683, 52 p.

Wolters, Gale L. 1972. Production and persistence of common carpetgrass in relation to site and harvest frequency. J. Range Manage. 25:360-364

Wolters, Gale L. 1973. Southern pine overstores influence herbage quality. J. Range Manage. 26:423-426. 